\title{
Evaluation of Differences Needs for Shotcrete Materials at the Haulage Level of Grasberg Block Cave (GBC) Underground Mine PT Freeport Indonesia
}

\author{
Friskila Nesya Gusti Krisdiana ${ }^{1}$, Hidayatullah Sidiq $^{2}$, Bayurohman Pangacella Putra ${ }^{3}$
}

\{friskilagk@gmail.com ${ }^{1}$, hidayatullah@itny.ac.id², bayurohman@itny.ac.id $\left.{ }^{3}\right\}$

Department of Mining Engineering Faculty of Mineral Technology Yogyakarta National Institute of Technology Yogyakarta, Indonesia

\begin{abstract}
To support underground mining activities, good and effective ground support is needed. Shotcrete is one of the ground supports applied in Grasberg Block Cave underground mine of PT. Freeport Indonesia. The research area is on Track 20 Level Haulage GBC PTFI. When spraying shotcrete there is always an increase in the amount of material planned (overspray) which causes a difference in the amount of material needs. The purpose of this research to evaluate the factor that affect difference in the amount of material needs. Quantitative research methods by collecting secondary data from companies. The results of this research shotcrete planning calculated by the dimensions of the tunnel heading, the total material needs is $192.576 \mathrm{~m} 3$. The actual results is $272 \mathrm{~m} 3$ from actual daily shotcrete data. Then evaluated from the difference in the amount of shotcrete material needs. The factors that cause an overspray is $41 \%$ from the total planning material affected by overbreak, over thickness up to $10 \mathrm{~cm}$, and rebound of $4.9 \%$. Efforts to reduce the amount of over shotcrete material needs by reducing the overbreak factor, reducing the percentage of material rebound and reducing the size of the over thickness from the minimum standard.
\end{abstract}

Keywords: Underground Mine, Ground Support, Shotcrete, Material Overspray

\section{Introduction}

PT Freeport Indonesia is a company engaged in copper, gold and silver mining, operating in the highlands of Mimika Regency, Papua Province, Indonesia. Currently, the operation has switched to the underground mining method. Grasberg Block Cave is one of the underground mines of PT Freeport Indonesia which is currently in production by applying the block caving mining method. The block caving method with high production targets requires reinforcement and support to produce good stability of the opening holes. To increase the stability of the openings in underground mines, the application of a ground support system is implemented in the openings. The application of support in the Grasberg Block Cave (GBC) area is shotcrete (shot concrete). 
In implementing shotcrete at PT Freeport Indonesia, it is necessary to consider the productivity problem of using shotcrete. In the application of shotcrete in the field, what often happens is the mismatch of the amount of material when mixing with the plan and wasting the material. The addition of material from the requirements of the overspray factor is often too large and not optimal. Therefore, in this study evaluating the addition of shotcrete material which resulted in differences in planning and actual. This research was conducted by calculating the actual amount of material wasted and knowing the factors that caused the material to be wasted. As well as taking precautions to reduce wasted material. In previous research, the engineering division added $240 \%$ material requirements when spraying as an overspray factor. (Said. M, 2020) The addition of material requirements is not optimal because in this study the overspray factor was only $41 \%$. This will increase the amount of material requirements and costs...

\section{Text formatting}

The method used in this research is quantitative method, which is one of the systematic, wellplanned and clearly structured research methods and research conclusions accompanied by pictures, tables, graphs or other displays. The following are the stages carried out in this research method: The initial stage in the implementation of this research is to conduct a literature study. Literature studies are carried out by searching for library materials in the form of books, research journals, and data from companies that can be used as support in conducting research. Data is sent directly from the field (secondary data). The following are the data needed in this study: Work Sheet Shotcrete, Time and activity of the shotcrete mixing process in the batching plan., Data on the dimensions of the research area heading. Shotcrete Equipment Rebound on spraying shotcrete. Output accelerator. Map of IUPK location PT Freeport Indonesia. Map of Track area 20 elevation 2760 Level Haulage Underground Mine Grasberg Block Cave (GBC). Standart Operational Procedure (SOP) Shotcrete. Specifications of the shotcrete equipment used. Ground Support Recommendation data on the research area. Data that has been collected in the field and from literature studies are grouped and then processed so as to obtain research results in accordance with the research objectives. The processed data is in the form of : The area to be shotcrete. Shotcrete material requirements. Mix shotcrete in the batching plant. Total Accelerator Output.,Shotcrete spraying technique that will affect the thickness and overspray that occurs.,Shotcrete sampling testing.,Analysis of the results of data processing was carried out with the aim of obtaining information which would later be used to draw conclusions. The data analyzed included :,Needs shotcrete material that is needed (plan) and what is used (actual).,The time required to install the shotcrete and the resulting daily target.,Testing shotcrete sampling and evaluating compliance with predetermined standards.,Analysis of the actual difference with the planning of shotcrete material requirements.,Conclusions are drawn from the results of data analysis carried out in accordance with the research objectives. So that it can be seen the amount of difference between actual shotcrete material needs and planning. And can provide recommendations to seek efficiency in the use of shotcrete material.

\section{Result}

A. Research Location 
Research and data collection activities were carried out in the area of Track 20 Level Haulage elevation 2760 underground mine Grasberg Block Cave (GBC) PT Freeport Indonesia. Data was collected during the shotcrete placement, namely August 13, 15-17, 2020.

\section{B. Shotcrete Application}

The mechanism for applying shotcrete in the field is the mixing of the material, which is then transferred to a mixer truck to be sent to the location to be shotcrete. The following is an application process for shotcrete in the field.

\section{a) Batching and Mixing}

The first process in applying shotcrete is batching and mixing in the batch plan area. Batching and mixing is the process of mixing shotcrete-forming materials which are then transferred to the SVS truck. The batch plant location in the Grasberg Block Cave area is in an underground mine so that it can facilitate access to the location to be shotcrete and can shorten delivery times.

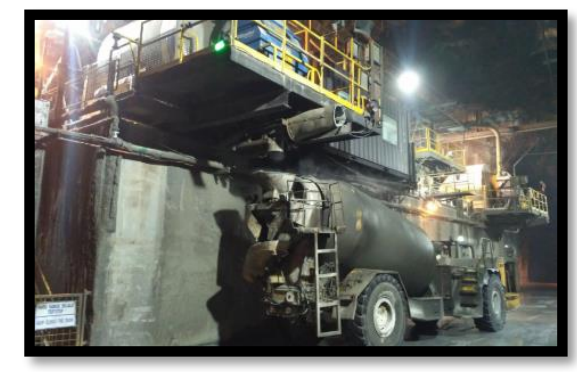

Fig. 1. Loading Point Shotcrete Material from the Batch Plant to the SVS Truck

In the process of mixing shotcrete material, it is adjusted to the mix design that has been planned and its strength value is tested. The following is the total volume and weight of shotcrete material that has been planned in the mix design at the Batch Plant.

Table 1. Mix Design Shotcrete Sand Fiber $40 \mathrm{MPa}$

\begin{tabular}{llll}
\hline Material & Quantity & Density $\mathbf{( k g / \mathbf { m } ^ { 3 } )}$ & Volume $(\mathbf{L})$ \\
\hline Sand & $1710 \mathrm{~kg}$ & 2,64 & 647,7 \\
\hline Cement & $550 \mathrm{~kg}$ & 3,150 & 174,6 \\
\hline Viscocrete & $4,2 \mathrm{~L}$ & 1,080 & 4,2 \\
\hline Sikatard & $2 \mathrm{~L}$ & 1,100 & 2 \\
\hline Water & $165 \mathrm{~L}$ & 1,000 & 165 \\
\hline Fiber & $6 \mathrm{~kg}$ & 0,9 & 5,4 \\
\hline Volume & Total $=$ & $\mathbf{9 9 8 , 9} \mathbf{C U M}$ &
\end{tabular}

b) Delivery Material

The second process is the material delivery process. After the shotcrete material is transferred to the SVS truck, then the material is sent to the heading location to be shotcrete. In the Track 20 Level Haulage area using an SVS Mixer with a capacity of $5 \mathrm{~m} 3$. 


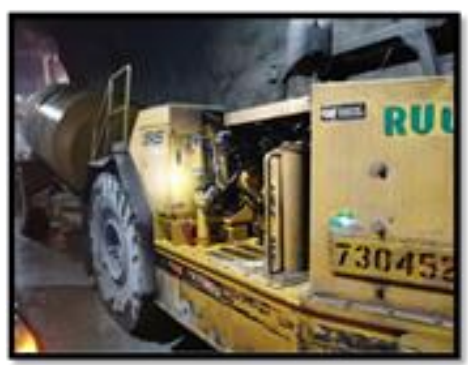

Fig. 2. SVS Truck 730452

c) Placement Shotcrete

After the material is carried by the SVS truck to the location to be shotcrete, the next process is placement (spraying) in accordance with the specified standards using the Jacon Maxijet tool.

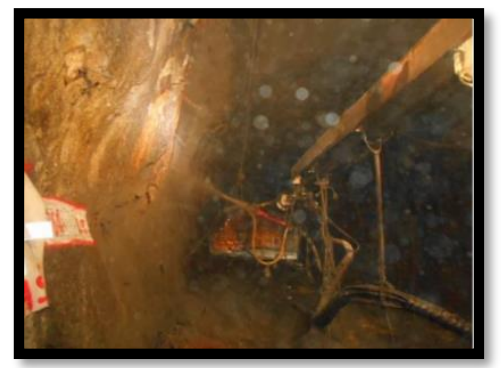

Fig. 3. Spraying Shotcrete at GC2760 Track 20

\section{Shotcrete Installation}

The determination of the shotcrete installation plan is based on the results of geotechnical analysis. Shotcrete is the primary buffering stage in the heading area. The type of shotcrete used in the area is wet shotcrete (wet mix).

a) Ground Support Recomendations

In the area of Track 20 Level Haulage elevation 2760 underground mine Grasberg Block Cave a geotechnical analysis is carried out to be able to provide recommendations for appropriate support in the area. In addition, to find out the sequence of mounting supports, thickness, strength, and the shotcrete design mix.

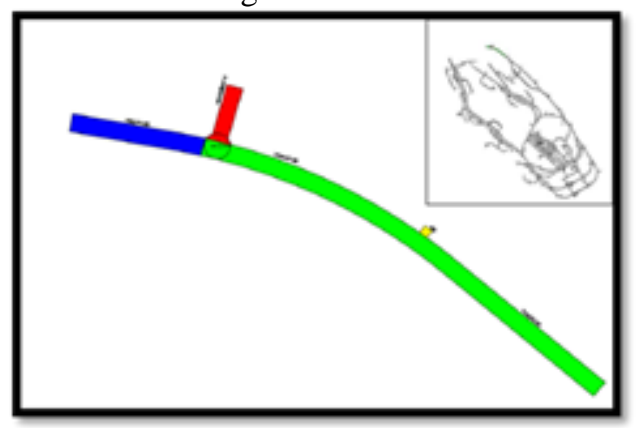

Fig. 4. Ground Support Layout Plan at GC 2760L Track 20 
In fig 4. is the layout of the area division plan that will be carried out by Ground Support (buffer). The area in green is the area where the research was carried out. The support plan that will be carried out in the green area is primary ground support with $0.075 \mathrm{~m}$ fibercrete installation, $0.0056 \mathrm{~m}$ weld mesh, $3 \mathrm{~m}$ MDX bolts or $3 \mathrm{~m}$ splitsets, and $6 \mathrm{~m}$ cable bolts.

b) Area of the Plan Heading

In determining the area of the area to be shotcrete, it is necessary to know the area of the heading area. The Track 20 Level Haulage area has the heading dimensions in Image 4. The thickness of the shotcrete that has been recommended by the Underground Geotechnical and Hidrology Department of PT Freeport Indonesia is $75 \mathrm{~mm}$ and an area length of $160.48 \mathrm{~m}$.

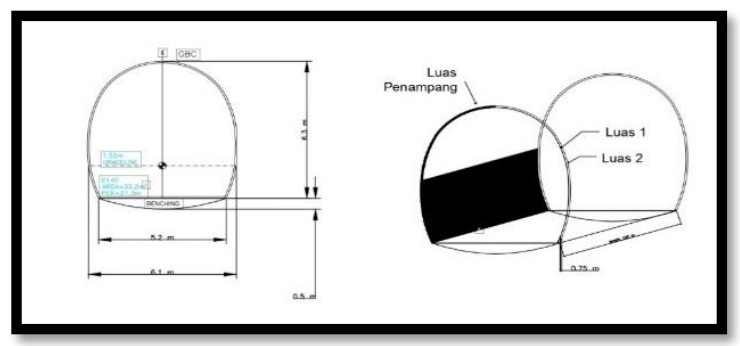

Fig. 5. Heading Tunnel Dimensions

\begin{tabular}{|c|c|c|c|c|c|c|c|}
\hline \multicolumn{3}{|c|}{ Heading Dimension } & \multirow{2}{*}{$\begin{array}{l}\text { Thick } \\
\text { (m) }\end{array}$} & \multirow{2}{*}{$\begin{array}{l}\text { Area of } \\
\text { Tunnel } \\
\text { Heading } \\
\left(\mathbf{m}^{2}\right)\end{array}$} & \multirow{2}{*}{$\begin{array}{l}\text { Area of } \\
\text { Shotcrete } \\
\text { Heading } \\
\text { (m) }\end{array}$} & \multirow{2}{*}{$\begin{array}{l}\text { Shotcrete } \\
\text { Cross } \\
\text { sectional } \\
\text { Area } \\
\left(\mathbf{m}^{2}\right)\end{array}$} & \multirow[b]{2}{*}{$\begin{array}{l}\text { Shotcrete } \\
\text { Volume } \\
\left(\mathrm{m}^{3}\right)\end{array}$} \\
\hline $\begin{array}{l}\text { Wide } \\
\text { (m) }\end{array}$ & $\begin{array}{l}\text { Hight } \\
\text { (m) }\end{array}$ & $\begin{array}{l}\text { Length } \\
\text { (m) }\end{array}$ & & & & & \\
\hline 6,61 & 6,3 & 160,48 & 0,075 & 33,2 & 32 & 1,2 & 192,576 \\
\hline
\end{tabular}

c) Planning (plan) the amount of shotcrete material

In the Track 20 Level Haulage elevation area of 2760, the planning for the number of shotcrete needs is $192.576 \mathrm{~m}^{3}$. The planning for the amount of shotcrete material is always incompatible with the application in the field. This is due to several influencing factors, such as the occurrence of an overbreak at the time of blasting so that it exceeds the planned heading dimensions. In addition, it is difficult for operators to control the thickness of the shotcrete according to geotechnical recommendations as well as the rebound factor when applying shotcrete.

d) Actual Amount of Shotcrete Material

Actual amount of shotcrete material can be determined from actual daily data obtained from the Batch Plant per CUM per day. Table 3.The following is the actual daily data in the research area. 
Table 3. Daily Actual Shotcrete

\begin{tabular}{|c|c|c|c|c|c|c|c|c|c|c|c|c|c|c|c|c|c|c|c|c|c|c|c|c|c|c|c|c|c|c|}
\hline \multicolumn{31}{|c|}{ DAILY ACTUAL (cum) } \\
\hline 1 & 2 & 3 & 4 & 5 & 6 & 7 & 8 & 9 & 10 & 11 & 12 & 13 & 14 & 15 & 16 & 17 & 18 & 19 & 20 & 21 & 22 & 23 & 24 & 25 & 26 & 27 & 28 & 29 & 30 & 31 \\
\hline $\mathbf{Q}$ & $Q$ & $Q$ & $Q$ & $Q$ & $Q$ & $Q$ & $Q$ & $Q$ & $Q$ & $Q$ & $\mathbf{Q}$ & $Q$ & $Q$ & $Q$ & $Q$ & $Q$ & $Q$ & $Q$ & $Q$ & $Q$ & $Q$ & $Q$ & $Q$ & $\mathbf{Q}$ & $Q$ & $Q$ & $Q$ & $Q$ & $Q$ & $Q$ \\
\hline$\cdot$ &. & . & . & . & . & . & . & . & . & . & . & 66 & . & 88 & 88 & 30 & . & . & . & . & . & . & . & . & . & . & . & . & . & . \\
\hline
\end{tabular}

In the daily table the actual shotcrete is the schedule for spraying shotcrete within 1 month in August 2020. With the heading dimensions of $6.10 \mathrm{Wx} 6.30 \mathrm{H}$ it only takes 4 days from 13 to 17 August 2020 to spray shotcrete. In the table, Q is the quantity of shotcrete material released from the batch plant. On the 13th it requires $66 \mathrm{CUM}$, the 15th and 16th requires $88 \mathrm{CUM}$, and the 17 th requires 30 CUM. The total material used for 4 days in the area was 272 CUM.

e) Overbreak Shotcrete

Overbreak is a change in the actual dimensions of the heading from the planned result of blasting. Overbreak can occur due to the rock type factor in the study area that is easily separated from the source rock. The following is the overbreak percentage data in the Track 20 Level Haulage area.

TABLE 4. Overbreak Percentage

\begin{tabular}{llll}
\hline Month & $2760 /$ L Haulage Level & $\begin{array}{l}\text { Percentage Volume } \\
\text { Overbreak from Design }\end{array}$ \\
\hline January & 2760 & Track 20 & $6,50 \%$ \\
\hline February & 2760 & Track 20 & $5,40 \%$ \\
\hline March & 2760 & Track 20 & $7,90 \%$ \\
\hline April & 2760 & Track 20 & $7,50 \%$ \\
\hline Average & & & $6,83 \%$ \\
\hline
\end{tabular}

Rebound on Shotcrete

When spraying shotcrete in the field, there is always material that falls to the surface and is wasted. This is a rebound, namely the result of material reflection that is not stuck to the rock wall, when a plug up occurs which causes the nozzle to release, when the material transfers from the mixer truck to the maxijet hopper, and the remaining material in the maxijet hopper.

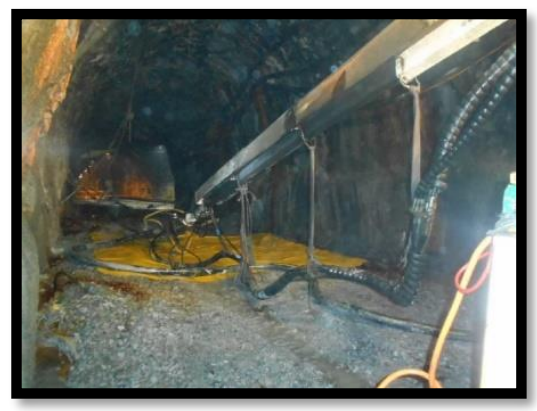

Fig. 5. Taking of Rebound Data on Shotcrete 
Measurement of rebound on shotcrete material in the field by taking samples during spraying. Retrieval of rebound data is as shown in Image 6., namely by providing a base on the surface of the tunnel floor when spraying shotcrete. Then the amount of material that falls on the base is counted by accommodating the fallen material and then measured using a box measuring $(49.5 \times 49.5 \times 28 \mathrm{~cm})$ with a volume of $0.0686 \mathrm{CUM}$. The rebound sample is completely filled in 3 boxes and 1 box is half filled. Total rebound reached $4.9 \%$ (0.245 CUM) from 1 mixer with a capacity of 5 CUM.

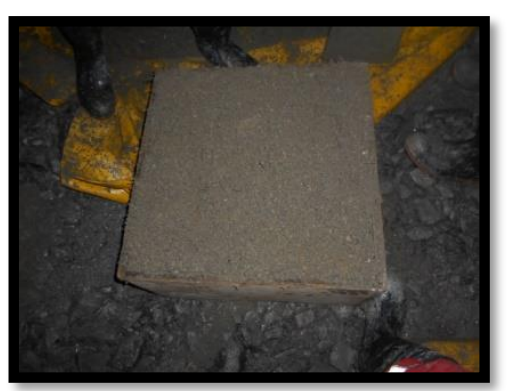

Fig. 6. Measurement of Sample Rebound

\section{Shotcrete Thickness}

The thickness recommended by PT Freeport Indonesia's Underground Geotechnical and Hidrology Department is $0.075 \mathrm{~m}$ minimum. Measurement of the actual thickness in the area using a coring sample.

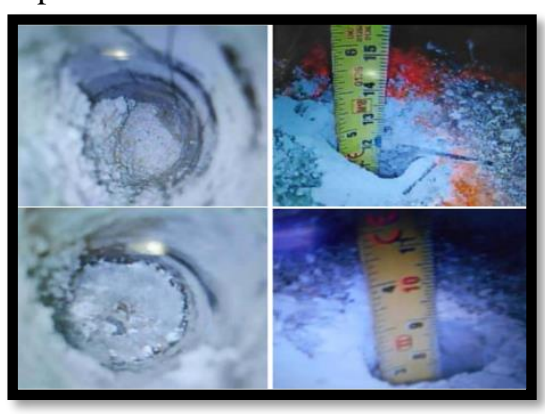

Fig. 7. Shotcrete Thickness Measurement

46 sample points were taken on the part of the tunnel wall for thickness measurements. On the roof of the tunnel, no sampling was carried out due to its location which was difficult to reach. From the measurement results at 46 sample points, all of them have a thickness size that is more than the predetermined minimum limit.

\section{Output Accelerator}

Measurement of the output accelerator used in the shotcrete mixture is a measuring cup and a stopwatch. The measurement is by taking the accelerator liquid in the maxijet machine using a measuring cup and then calculating the amount of accelerator fluid that 
comes out of the nozzle within 1 minute. Standard dosage using accelerator is $4 \%-7 \%$ by weight of cement $\left(\mathrm{m}^{3}\right)$. From the calculation, the results of the accelerator output used are $6 \%$.

TABLE 5. Output Accelerator

\begin{tabular}{llllll}
\hline Research Location & $\begin{array}{l}\text { Output } \\
\left(\mathbf{k g} / \mathbf{m}^{\mathbf{3}}\right)\end{array}$ & Acc & $\begin{array}{l}\text { Actual } \\
\text { Cement/m } \\
(\mathbf{k g})\end{array}$ & $\%$ & $\begin{array}{l}\text { Standart } \\
\text { Suitabili } \\
\text { ty }\end{array}$ \\
\hline $\begin{array}{l}\text { Track 20 } \\
\text { Haulage }\end{array}$ & Level & 33,75 & 550 & $6 \%$ & yes \\
\hline
\end{tabular}

D. Factors Affecting the Excess Amount of Use of Shotcrete Material

a) Overbreak Factor

The overbreak factor results in a mismatch of the actual planned volume of material. Engineer sets an overbreak of $<10 \%$ of the blasted volume. If more, it needs special handling with premier support. The average overbreak value in the Track 20 Level Haulage area is $6.83 \%$.

\section{b) Overspray Factor}

Overspray is the percentage of excess material that is adhered to the material that is not stuck (wasted material) at the time of installation of the shotcrete. Engineers set a tolerable overspray limit of $240 \%$. The results obtained were as much as $41 \%$ overspray of the planned amount of material requirements.

\begin{tabular}{|c|c|c|c|c|c|}
\hline Location & $\begin{array}{l}\text { Plan (mixer } \\
\text { capacity) } \mathbf{m}^{3}\end{array}$ & $\begin{array}{l}\text { Shotcrete } \\
\text { Needs }\end{array}$ & $\begin{array}{l}\text { Actual } \\
\text { Shotcrete } \\
\left(\mathbf{m}^{3}\right)\end{array}$ & $\begin{array}{l}\text { Excess } \\
\text { Material } \\
\left(\mathbf{m}^{\mathbf{3}}\right)\end{array}$ & $\begin{array}{l}\text { Overspray } \\
(\%)\end{array}$ \\
\hline $\begin{array}{l}\text { Track } 20 \\
\text { Level } \\
\text { Haulage }\end{array}$ & 5 & 192,58 & 272 & 79,42 & $41 \%$ \\
\hline
\end{tabular}

c) Thickness Factor

Actual spraying of shotcrete in the field often cannot be done optimally so that it can affect the size of its thickness. This is because the operator (nozzle man) is difficult to estimate the thickness during the shotcrete spraying process. The actual thickness size in the field is thicker up to $10 \mathrm{~cm}$. The standard that has been determined for the thickness of the shotcrete in the Track 20 Level Haulage area is a minimum of $7.5 \mathrm{~cm}$.

d) Rebound Factor

Rebound is the material that bounces when shotcrete is sprayed which causes a large amount of material to be wasted. The total rebound generated from taking one mixer used to spray shotcrete in the study area was $4.9 \%$. Rebound standard that is tolerated 5-10\%.

E. Evaluation of the Difference in the Amount of Shotcrete Material Needs 
The difference in the amount of shotcrete material needs from the planned (plan), namely $192.576 \mathrm{~m} 3$ and the actual field to $272 \mathrm{~m} 3$ is caused by several technical factors as previously explained. The wasted material will increase the company's operational costs. Therefore it is necessary to do an evaluation to make the excess use of the material more efficient. The following is an attempt to reduce the excess use of shotcrete material. Reducing the overbreak factor during blasting activities by carrying out more detailed planning and control after blasting and material hauling activities. Reducing the amount of the percentage of overspray by controlling the factors that cause overspray. To reduce the size of the shotcrete thickness that exceeds the minimum limit, when spraying can be done by dividing several steps. So that the excess thickness is not too much. Spray in a circular or circular manner. By not dripping on a point and moving when the wall begins to close the shotcrete as it will give an uneven thickness. And install a thickness indicator before spraying using the plate affixed to the heading. Minimizing the amount of rebound when spraying with a standard nozzle angle of 750 - 900 from rock walls. Before spraying, it is necessary to do substrate cleaning or headings cleaning with water until it is completely wet and evenly distributed on each rock surface, so that the rock is clean from dust which will interfere with the process of placing the shotcrete material on the rock

\section{Conclusion}

From the results of research data analysis which is then carried out a discussion, a conclusion can be drawn, namely: The area of the plan heading in the Track 20 Level Haulage area of PT Freeport Indonesia's Grasberg Block Cave Underground Mine which is used as a research area is $33.2 \mathrm{~m} 2$ with a length of $160 \mathrm{~m}$. Planning the amount of shotcrete material needed is 192.576 $\mathrm{m}^{3}$, while the actual amount of shotcrete material used is $272 \mathrm{~m}^{3}$. The difference between the amount of material and the actual was $41 \%$ overspray. The factor that causes differences in the amount of shotcrete material is the overbreak factor with an average value of $8.9 \%$ in the study area. Thickness factor in thicker pitches up to $10 \mathrm{~cm}$. And the rebound factor with a value of $4.9 \%$ when taking one mixer SVS truck with a capacity of $5 \mathrm{~m}^{3}$. 


\section{References}

[1.] Agustawijaya, D. S., 2019. Geologi Teknik. Yogyakarta: ANDI.

[2.] Docslide, 2019. Sistem Penyanggaan Shotcrete. [Online] Available at: https://dokumen.tips/doCUMents/bab- 13-penyangga-beton.html.

[3.] [Accessed 63 2020]

[4.] Ginting A. Purba, S. A., 2017. Inovasi Sistem Penyanggaan di Tambang Bawah Tanah DMLZ PT. Freeport Indonesia. Simposium II UNIID , pp. 429-435

[5.] Said, M., 2020. Analisis Teknis Penggunaan Shotcrete Pada Tambang Bawah Tanah Grasberg Block Cave (GBC) di PT Freeport Indonesia Provinsi Papua. Prosiding TPT XXIX PERHAPI 2020.

[6.] ...., 2003. ASTM C143 / C143M - 00. In: Standard Test Method for Slump of Hydraulic Cement Concrete. West Conshohocken PA: ASTM International.

[7.] ...., 2007. ASTM C 39-14. In: Standard Test Method for Compressive Strength of Cylindrical. West Conshoshocken PA: ASTM International. 